\title{
Uniformity microsprinkler irrigation system using statistical quality control
}

\author{
Maurício Guy de Andrade ${ }^{1 *}$ Marcio Antonio Vilas Boas ${ }^{1}$ Jair Antonio Cruz Siqueira $^{2}$ \\ Mireille Sato ${ }^{2}$ Jonathan Dieter ${ }^{3}$ Eliane Hermes ${ }^{3}$ Erivelto Mercante ${ }^{1}$
}

\begin{abstract}
${ }^{1}$ Programa de Pós-graduação em Engenharia Agrícola (PGEAGRI), Universidade Estadual do Oeste do Paraná (UNIOESTE), 85819-110, Cascavel, PR, Brasil. E-mail: mauricio.agro@hotmail.com. .Corresponding author.

${ }^{2}$ Programa de Pós-graduação em Engenharia de Energia na Agricultura (PPGEA), Universidade Estadual do Oeste do Paraná (UNIOESTE), Cascavel, PR, Brasil. ${ }^{3}$ Departamento de Engenharias e Exatas (DEE), Universidade Federal do Paraná (UFPR), Palotina, PR, Brasil.
\end{abstract}

ABSTRACT: The objective of this study was to evaluate the use of statistical quality control tools in the analysis of the uniformity of a microsprinkler irrigation system. For the analysis of irrigation Christiansen uniformity coefficient (CUC) and the distribution uniformity coefficient (DU) were statistically analyzed by means of the Shewhart control charts and process capability index (Cp). For the experiment 25 tests were carried out with a single micro sprinkler and subsequently seven different spacing between micro sprinklers were simulated. Control charts contributed to the diagnosis of the treatments to be under control and with satisfactory uniformity outcomes. Increase in process capability index was directly proportional to the average of CUC and DU.

Key words: Christiansen uniformity coefficient, distribution uniformity coefficient, control charts, process capability index.

Uniformidade da irrigação por microaspersão utilizando o controle estatístico de qualidade

RESUMO: $O$ estudo objetivou avaliar o uso das ferramentas do controle estatistico de qualidade na análise da uniformidade de um sistema de irrigação por microaspersão. Para a análise da irrigação foram utilizados os coeficientes de uniformidade de Christiansen (CUC) e o coeficiente de uniformidade de distribuição (CUD), e estes foram analisados estatisticamente através dos gráficos de controle de Shewhart e do indice de capacidade do processo (Cp). Para o experimento foram realizados 25 ensaios com um único microaspersor, sendo posteriormente simulados sete diferentes espaçamentos entre microaspersores. Os gráficos de controle contribuíram para o diagnóstico dos tratamentos sob controle e com resultados satisfatórios de uniformidade. O aumento do índice de capacidade do processo mostrou-se diretamente proporcional as médias dos valores de CUC e CUD.

Palavras-chave: coeficiente de uniformidade de Christiansen, coeficiente de uniformidade de distribuição, gráficos de controle, indice de capacidade do processo.

\section{INTRODUCTION}

Micro sprinkler irrigation produces positive yields in relation to water savings and increases crop productivity, but one of the concerns is the uniform distribution, which is the spatial distribution irrigation applied in a regular way throughout the area, once micro sprinklers tend to have low uniformity of application over the wet area (KOUMANOV et al., 2006).

Uniformity is also an important factor in the acquisition of equipment (BRAUER et al., 2011) and it is one of the most important elements for irrigation, since it directly influences the agricultural productivity (BRAUER et al., 2011; JUSTI et al., 2010; BRENNAN, 2008; KELLER, 2002).

For the analysis of irrigation parameters such as uniformity, statistic quality control techniques can be used, such as Shewhart control charts and process capability index. JUSTI et al. (2010) used the process quality control by means of the control charts and/or process capability index to evaluate a sprinkler irrigation system, as well as HERMES et al. (2015), HERMES et al. (2014), HERMES et al. (2013), KLEIN et al. (2015) and JUCHEN et al. (2013) also used the statistic tools of process quality control, but in a drip irrigation system. All these authors concluded that the process capability index is directly proportional to the increase of the system uniformity, with the ability to monitor the irrigation control within satisfactory limits, besides the control charts contribute to the monitoring of the irrigation process.

Therefore, presuppose that the greater the spacing between micro sprinklers lower is the uniformity of irrigation distribution, considering the reliable tools of statistical quality control for more 
accurate diagnoses on the variability during the process. In accordance with the stated, the objective was to evaluate statistical control tools, the Shewhart control charts and the process capacity index, for the analysis of distribution uniformity coefficients.

\section{MATERIALS AND METHODS}

Irrigation tests took place in the CASA Project Laboratory (Alternative Energy Systems Analysis Center), at the Universidade Estadual do Oeste do Paraná (UNIOESTE), campus Cascavel, without the influence of external factors such as solar radiation and wind.

For the conduction of irrigation tests a system powered by solar energy by means of a photovoltaic panel composed of three modules with nominal power of $50 \mathrm{~W}$ was assembled. Such a solar energy system was connected to an energy storage unit which was connected to a charge controller. The hydraulic pump used is a diaphragm one with a maximum flow rate of $490 \mathrm{~L} \mathrm{~h}^{-1}$ and with manometric capacity of $207 \mathrm{kPa}$. The micro sprinkler has a wet diameter of $6.0 \mathrm{~m}$, a $41 \mathrm{~L} \mathrm{~h}^{-1}$ flow when working under a pressure of $200 \mathrm{kPa}$ and the equipment is $0.25 \mathrm{~m}$ high from soil (Figure 1).
The adopted methodology for data collection use a total of 100 catch-can collectors were positioned in a mesh pattern, with a $0.50 \mathrm{~m}$ gap between them. The test time used was one-hour and, with completely randomized design was chosen, with 25 replicates for treatment, with the following: T1 - 1.0m x 1.0m spacing; $\mathrm{T} 2-1.0 \mathrm{~m} \times 1.5 \mathrm{~m}$ spacing; $\mathrm{T} 3-1.5 \mathrm{~m} \times 1.0 \mathrm{~m}$ spacing; T4 - 1.5m x $1.5 \mathrm{~m}$ spacing; T5 - $1.5 \mathrm{~m} \times 2.0 \mathrm{~m}$ spacing; T6 - 2.0m x $1.5 \mathrm{~m}$ spacing; $\mathrm{T} 7-2.0 \mathrm{~m} \times 2.0 \mathrm{~m}$ spacing.

For each of these spacing combination simulation it was calculated the uniformity with the totals overlaid on each collector and also average, standard deviation, normality by the ANDERSON \& DARLING (1952) method, data autocorrelation and coefficient of variation.

In order to evaluate the irrigation system, it was used the Christiansen Uniformity Coefficient (CUC), proposed by CHRISTIANSEN (1942) and the Distribution Uniformity Coefficient (DU), developed by MERRIAM \& KELLER (1978).

To monitor the uniformity coefficients Shewhart control charts were built, aiming to investigate the parameters during testing, making it necessary to calculate the Upper Control Limit (UCL) and Lower Control Limit (LCL), using equations 01 and 02 , in order to determine the graphs.

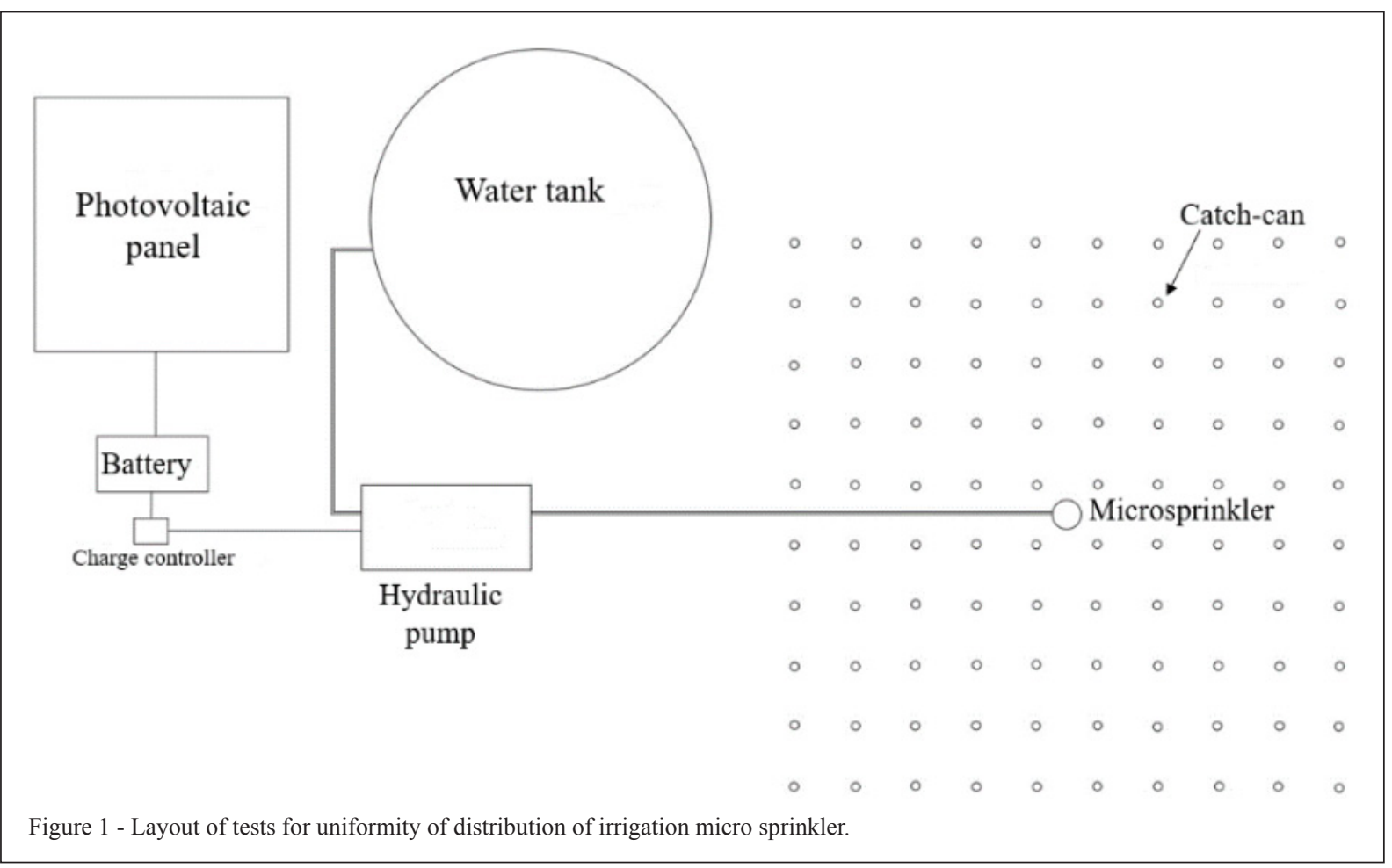

Ciência Rural, v.47, n.4, 2017. 


$$
\begin{gathered}
\mathrm{UCL}=\bar{x}+\frac{3 M R}{\mathrm{~d}_{2}} \\
\mathrm{LCL}=\bar{x}+\frac{3 \mathrm{MR}}{d_{2}}
\end{gathered}
$$

in which USL = upper control limit; LCL $=$ lower control limit; $\bar{x}=$ average; $\mathrm{MR}=$ mobile range of observations; $\mathrm{d}_{2}=$ predetermined value (tabulated $=$ 3.931).

In order to evaluate the process capability, the methodology proposed by MONTGOMERY (2009) was used, in which the process capability index $(\mathrm{Cp})$ is calculated and then used when the process is stable, that is, with statistical control and when the distribution of variable of interest is close to normal. When the process is stable, Cpk (unilateral processes), defined according to the equations 3 and 4 , is applied. Cpk is the lower value between $\mathrm{Cpu}$ (upper) and $\mathrm{Cpl}$ (lower), as shown in equation 05.

$$
\begin{aligned}
& C p l=\frac{\bar{x}-L C L}{3 \sigma} \\
& C p u=\frac{U C L-\bar{x}}{3 \sigma} \\
& C p k=(C p l ; C p u)
\end{aligned}
$$

in which $\sigma=$ standard deviation.

The process classification for uniformity values proposes as capable or suited those with $C p \geq 1.45$, given that processes are considered new and with unilateral specifications (MONTGOMERY, 2009).

\section{RESULTS AND DISCUSSION}

CUC and DU averages increased as the spacing between the micro sprinklers was smaller (Table 1). Standard deviation is higher for DU values when compared to CUC, significantly influencing the calculation of the process capability index.

The tests showed high uniformity levels, with CUC values from $85.92 \%$ to $95.97 \%$, similar to those reported by HOLANDA FILHO et al. (2001) who performing the hydraulic characterization of a micro sprinkler, obtained CUC results from $85.2 \%$ to $96.6 \%$, similar to the average values of SILVA \& SILVA (2003) of $95.47 \%$, considered from good to excellent according to MANTOVANI (2002) classification.

When compared to other irrigation systems, CUC and DU values are correlated with the current tests, as well as with the results of FARIA et al. (2016) that, when evaluating the influence of wind on a sprinkler irrigation system with movable side reported CUC between $85 \%$ and $93.86 \%$ and DU from $76.71 \%$ to $89.26 \%$. The high values of the coefficients were due to the control of variable pressure, use of a new micro sprinkler and use of an energy storage system.

For subsequent building of Shewhart control charts and calculation of the process capability index is suggested, according to MONTGOMERY (2009), that data is normally distributed and have no autocorrelation between them. According to the Anderson-Darling normality test, with a significance level of $5 \%$, for CUC, treatment with T6 is not normal and treatments with DU, T2 and T5 are not normal (Table 1). Data autocorrelation was detected in treatment 2 in the case of CUC and treatment T1 in the case of DU; therefore, such treatments and those that did not presented normality were discarded for statistical quality control techniques purposes.

From Shewhart control charts (Figure 2) building and from the analysis of the CUC, it is possible to notice that treatments $\mathrm{T} 1, \mathrm{~T} 3, \mathrm{~T} 5$ and $\mathrm{T} 7$ are under control because none of them reaches points outside the upper and lower control limits nor presents undesirable settings as a trend or sequence (MONTGOMERY, 2009). Treatment T4 does not reach any points outside the control limits, but presents a sequence below midline, from tests 14 to 20 which is an indication of lack of control. For MONTGOMERY (2009), when seven consecutive values are above or below the midline it constitutes a data tendency and by assumption a probable lack of statistical control.

Analyzing the data distribution in relation to the $90 \%$ value line, which is for MANTOVANI (2002) the minimum irrigation uniformity value that can be classified as excellent, T1 and T3 have all values above the line and so they are the most appropriate spacing in relation to the distribution uniformity for CUC parameter, according to the control chart.

Regarding the illustrated DU parameter in figure 2, T3, T5 and T7 treatments are under statistical control and although treatment $\mathrm{T} 7$ of the tests 15 to 20 have values above midline, it is not considered as a trend (MONTGOMERY, 2009). Treatment T4 does not presents statistical control because test 10 is below the lower control limit, even if its values are above the $80 \%$ line and classified as good, according to BRALTS (1986).

As demonstrated in the control charts for the DU, no treatment presents all data above $90 \%$, to be classified as excellent and only treatment $\mathrm{T} 3$ has all values above $80 \%$ rated as good uniformity, due to the high variability of the collected flow. 
Table 1 - Descriptive statistics of uniformity coefficients.

\begin{tabular}{lcccccccc}
\hline Treatment & Mean CUC & SD CUC & CV CUC & p-value CUC & Mean DU & SD DU & CV DU & P-value DU \\
\hline T1 & 95.97 & 1.57 & 1.64 & 0.582 & 94.54 & 2.44 & 2.58 & 0.214 \\
T2 & 95.28 & 1.06 & 1.11 & 0.802 & 91.18 & 2.77 & 3.04 & $<0.005^{*}$ \\
T3 & 94.50 & 1.78 & 1.88 & 0.744 & 91.56 & 2.95 & 3.22 & 0.483 \\
T4 & 92.76 & 1.03 & 1.11 & 0.677 & 88.24 & 2.85 & 3.23 & 0.348 \\
T5 & 92.08 & 1.57 & 1.71 & 0.824 & 88.02 & 2.73 & 3.11 & $0.036^{*}$ \\
T6 & 87.32 & 1.63 & 1.87 & $0.005^{*}$ & 81.48 & 2.98 & 3.66 & 0.230 \\
T7 & 85.92 & 1.27 & 1.48 & 0.749 & 79.51 & 2.13 & 2.67 & 0.262 \\
\hline
\end{tabular}

Notes: *Non-normal values. lower than the significance level of 0.05 . calculated according to Anderson Darling normality test.; SD: standard deviation; $\mathrm{CV}$ : coefficient variation in $\%$; T1: $1.0 \mathrm{~m} \times 1.0 \mathrm{~m}$ spacing; $\mathrm{T} 2: 1.0 \mathrm{~m} \times 1.5 \mathrm{~m}$ spacing; $\mathrm{T} 3: 1.5 \mathrm{~m} \times 1.0 \mathrm{~m}$ spacing; T4: $1.5 \mathrm{~m}$ x $1.5 \mathrm{~m}$ spacing; T5: $1.5 \mathrm{~m}$ x 2.0m spacing; T6: $2.0 \mathrm{~m}$ x $1.5 \mathrm{~m}$ spacing; $77: 2.0 \mathrm{~m} \times 2.0 \mathrm{~m}$ spacing.

HERMES et al. (2013), HERMES et al. (2014) e HERMES et al. (2015) analyzing drip irrigation based on Shewhart control charts verified the occurrence of values below the lower control limit. JUCHEN et al. (2013) applied the control charts for drip irrigation for lettuce crop and obtained all tests results under control. JUSTI et al. (2010) using Shewhart control charts to study the uniformity of sprinkler irrigation detected one of the tests above the upper control limit (UCL) and none below the lower control limit (LCL).

Regarding the process capability index (Table 2) it was only considered the lower limit control. The value of $80 \%$ was classified as good and $90 \%$ as excellent for CUC and DU.Analyzing the new processes and unilateral specifications, MONTGOMERY (2009) classifies values above 1.45 as appropriate process. Therefore, for $\mathrm{CUC}$ is noted that when considering $\mathrm{LCL}=90 \%$ there are no appropriate treatments, but when considering $\mathrm{LCL}=80 \%$, all available treatments were considered appropriate. It has also been observed that for DU parameter no treatment was considered adequate in both LCLs.

Although most processes are classified as insufficient, there has been a directly proportional behavior between the average of uniformity coefficients and $\mathrm{Cpl}$, and for $\mathrm{CUC}$ parameter the relationship between variables is expressed by the equation CUC $(\%)=87.107+7.4473 \mathrm{Cpl}$, with a coefficient of determination of $\mathrm{R}^{2}=88.13 \%$ for $\mathrm{LCL}$ $=90 \%$; however when applying $\mathrm{LCL}=80 \%$ for CUC the equation is $\mathrm{CUC}(\%)=84.12+2.8273 \mathrm{Cpl}$, with $\mathrm{R}^{2}=50.85 \%$.

For CUD parameter, the relationship between the variables cannot be expressed for
$\mathrm{LCL}=90 \%$, considering that most of the values were equal to zero. Though for $\mathrm{LCL}=80 \%$ the relationship can be expressed by DU $(\%)=79.70+8.4425 \mathrm{Cpl}$, with $\mathrm{R}^{2}=98.26$

Equations for the CUC parameter with $\mathrm{LCL}=90 \%$ and DU with $\mathrm{LCL}=80 \%$ showed a strong correlation between the variables, because they both have high $\mathrm{R}^{2}$ values. For each $\mathrm{Cpl}$ unit that can be controlled in the process the value of the CUC and DU increases by 7.4473 and 8.4425 respectively; thus, demonstrating the importance of controlling the variability of the process to acquire high uniformity values.

For studies with drip irrigation, HERMES et al. (2013), HERMES et al. (2014) e KLEIN et al. (2015) detected that as CUC value increases, the process capacity index also increases, with a coefficient of determination $\mathrm{R}^{2}$ of $70.35 \%, 61 \%$ and $91.84 \%$, respectively. The same relation is established to DU values, according to HERMES (2015), with a $\mathrm{R}^{2}$ of $70.10 \%$ for $\mathrm{LCL}=90 \%$ and $85.7 \%$ for $\mathrm{LCL}=$ $80 \%$. JUSTI et al. (2010) also concluded the directly proportional relation of uniformity coefficients with $\mathrm{Cpl}$ and $\mathrm{R}^{2}$ of $78 \%$ when they studied the sprinkler irrigation process.

In the research, according to the control tools used, variations of the tests; however, minor, manly pressure, influenced the proper ratings of processes, even with high uniformity values, these being proper tools for the diagnosis of uniformity micro sprinkler irrigation.

\section{CONCLUSION}

Control charts were adjusted to detect the treatments under control and the most suitable spacing 


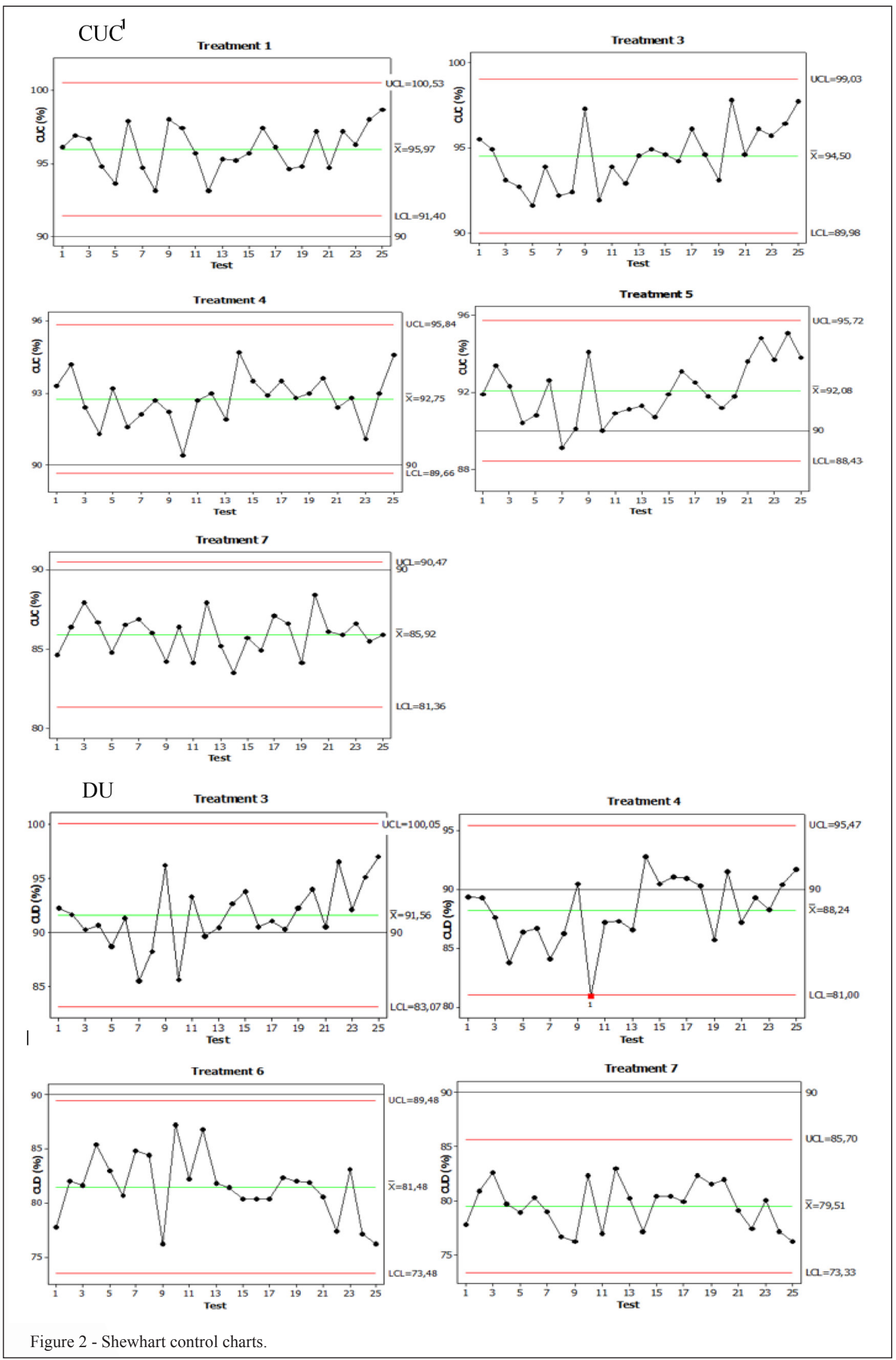

Ciência Rural, v.47, n.4, 2017. 
Table 2 - Process capability index.

\begin{tabular}{|c|c|c|c|c|}
\hline \multirow[t]{2}{*}{ Treatment } & \multicolumn{2}{|c|}{------------------------------'CUC-------------------------------- } & \multicolumn{2}{|c|}{---------------------------------DU---------------------------' } \\
\hline & $\mathrm{Cpl}$ LCL $=90 \%$ & $\mathrm{Cpl}$ LCL $=80 \%$ & $\mathrm{Cpl}$ LCL $=90 \%$ & Cpl LCL $=80 \%$ \\
\hline $\mathrm{T} 1$ & 1.27 & 3.39 & * & * \\
\hline $\mathrm{T} 2$ & * & * & * & * \\
\hline $\mathrm{T} 3$ & 0.84 & 2.72 & 0.18 & 1.31 \\
\hline $\mathrm{T} 4$ & 0.90 & 4.15 & 0.00 & 1.16 \\
\hline T5 & 0.44 & 2.56 & ${ }^{*}$ & * \\
\hline T6 & $*$ & * & 0.00 & 0.17 \\
\hline $\mathrm{T} 7$ & 0.00 & 1.55 & 0.00 & 0.00 \\
\hline
\end{tabular}

Notes: ${ }^{*}$ Cannot calculate the process capability index for non-normality. according Anderson-Darling normality test with 0.05 significance level. or autocorrelation between data; $\mathrm{T} 1: 1.0 \mathrm{~m} \times 1.0 \mathrm{~m}$ spacing; $\mathrm{T} 2: 1.0 \mathrm{~m} \times 1.5 \mathrm{~m}$ spacing; $\mathrm{T} 3: 1.5 \mathrm{~m} \times 1.0 \mathrm{~m}$ spacing; $\mathrm{T} 4: 1.5 \mathrm{~m} \times 1.5 \mathrm{~m}$ spacing; T5: $1.5 \mathrm{~m} \times 2.0 \mathrm{~m}$ spacing; $\mathrm{T} 6: 2.0 \mathrm{~m} \times 1.5 \mathrm{~m}$ spacing; $\mathrm{T} 7: 2.0 \mathrm{~m} \times 2.0 \mathrm{~m}$ spacing.

the detected treatments are $1.0 \mathrm{~m} \times 1.0 \mathrm{~m}$ spacing for Christiansen uniformity coefficient and $1.5 \mathrm{~m} \times 1.0 \mathrm{~m}$ spacing for distribution uniformity coefficient.

The process capacity index increase is directly proportional to CUC and DU average test value, with $\mathrm{R}^{2}$ above $80 \%$ in most cases, with smaller spacing with higher index capacity. Therefore, the statistical quality control is adequate for the analysis of the distribution uniformity of the micro sprinkler.

\section{REFERENCES}

ANDERSON, T. W.; DARLING, D. A. Asymptotic theory of certain goodness-of-fit criteria based on stochastic processes. Annals of Mathematical Statistics, v.23, p.193-221, 1952.

BRALTS, V. F. Field performance and evaluation. In: NAKAYAMA, F. S.; BUCKS, D. A. (Eds.). Amsterdam, 1986. p.216-240.

BRAUER, R. L. et al. Evaluation of the uniformity of water application in drippers as a function of iron content. Irriga, v.16, n.1, p.21-30, 2011. Available from: <http://revistas.fca.unesp. br/index.php/irriga/article/viewFile/188/97>. Accessed: Oct. 20, 2015. doi: 10.15809/irriga.2011v16n1.

BRENNAN, D. Factors affecting the economic benefits of sprinkler uniformity and their implications for irrigation water use. Irrigation Science, v.26, n.2, p.109-119, 2008. Available from: <http://link.springer.com/article/10.1007/ s00271-007-0077-9>. Accessed: Sept. 29, 2016. doi: 10.1007/s00271-007-0077-9.

CHRISTIANSEN, J. E. Irrigation by sprinkling. Berkely: University of California, Experiment Station, 1942. 124p. Bulletin, 670 .

FARIA, L. C. et al. Influence of the Wind on water application uniformity of a mechanical lateral move irrigation equipment using rotating plate sprinklers. Ciência Rural, v.46, n.1, p.83-88, 2016. Available from: <http://www.scielo.br/pdf/cr/v46n1/1678-4596- cr-0103 8478cr20141558.pdf>. Accessed: Jan. 23, 2016. doi: $10.1590 / 0103-8478 \mathrm{cr} 20141558$.

HERMES, E. et al. Process capacity index in drip irrigation with cassava wastewater processing. African Journal of Agricultural Research, v.10, p.1427-1433, 2015. Available from: <http:// www.academicjournals.org/journal/AJAR/article-full-textpdf/8F6687551836>. Accessed: July 30, 2015. doi: 10.5897/ AJAR2015.9610.

HERMES, E. et al. Irrigation with wastewater from cassava processing with diferente concentrations of suspended solids. International Journal of Food, Agriculture and Environment (Print), v.12, p.487-490, 2014. Available from: <http://worldfood.net/irrigation-with-wastewater-from-cassava-processingwith-different-concentrations-of-suspended-solids $>$. Accessed: Aug 07, 2015.

HERMES, E. et al. Quality control in irrigation and fertigation with cassava processing wastewater into drip system. International Journal of Food, Agriculture and Environment (Print), v.11, p.841-845, 2013. Available from: <http://worldfood.net/quality-control-in-irrigation-and-fertigation-withcassava-processing-wastewater-into-drip-system $>$. Accessed: Aug 07, 2015.

HOLANDA FILHO, R. et al. Hydraulic characterization of the Plastro Rondo microsprinkler. Revista Brasileira de Engenharia Agrícola e Ambiental, v.5. n.1, p.1621, 2001. Available from: <http://www.scielo.br/scielo. php? script $=$ sci_arttext\&pid $=\mathrm{S} 1415-43662001000100004>$. Accessed: July 30, 2015.

JUCHEN, C. R. et al. Drip irrigation for the production of fertirrigated lettuce with agroindustrial wastewater. Irriga, v.18, n.1, p.243-256, 2013. Available from: <http://irriga.fca.unesp.br/ index.php/irriga/article/view/408/364>. Accessed: Sept. 27, 2016. doi: 10.15809/irriga.2013v18n2p243.

JUSTI, A. L. et al. Índice de capacidade do processo na avaliação da irrigação por aspersão. Eng Agríc, v.30, n.2, p.264-270, 2010. Available from:<http://www.scielo.br/scielo. php?script $=$ sci_arttext\&pid=S0100-69162010000200008>. Accessed: 30 July, 2015. 
KELLER, J. Evolution of drip/microirrigation: traditional and non-traditional uses. Keynote address, International Meeting on Advances In Drip/Microirrigation, p. 2-5, December, 2002, Tenerife, Spain.

KLEIN, M. R. et al. Fertigation quality with drip irrigation system in grape orchard by using the process capability index. International Journal of Food, Agriculture and Environment, v.13, p.179-183, 2015. Available from: <http:// world-food.net/fertigation-quality-with-drip-irrigation-systemin-grape-orchard-by-using-the-process-capability-index $>$. Accessed: 07 Aug, 2015.

KOUMANOV, K. S. et al. Spatial and temporal distribution of root water uptake of an almond tree under microsprinkler irrigation. Irrigation Science, v. 24, n. 267, 2006. Available from: <http://link.springer.com/ article/10.1007/s00271-005-0027-3>. Accessed: 30 Jun, 2015.
MANTOVANI, E. C. Avalia: manual do usuário. Viçosa, EMBRAPA, 2002. 100p.

MERRIAN, J. L.; KELLER, J. Farm irrigation system evaluation: a guide for management. Logan: Agricultural and Irrigation, Engineering Department, 1978. Chapter XI: Basin Irrigation.

MONTGOMERY, D. C. Introdução ao controle estatístico de qualidade. Tradução: FARIAS, A. M. L., FLORES, V. R. L. F., LAURENCEL, L. C. 4. Editora LTC, 2009.

SILVA, R. A.; SILVA, A. M. Evaluation of the hydraulic characteristics of the Dan Jet 7200 self-compensating Microdiffuser. Ciência e Agrotecnologia, v.27, n.4, p.873-878, 2003. Available from: <http://www.scielo.br/pdf/cagro/v27n4/ v27n4a20.pdf>. Accessed: 07 Aug, 2015. 